\title{
PENINGKATKAN KREATIVITAS DAN HASIL BELAJAR PAI MATERI PERKEMBANGAN ILMU PENGETAHUAN PADA MASA ABASIYAH MELALUI PEMANFAATAN ALAT PERAGA TeTeS TeLOr BAGI SISWA KELAS XI MIPA 2 SMA NEGERI 1 ABUNGSEMULI PADA SEMESTER 2 TAHUN AJARAN 2019/2020
}

\author{
${ }^{1}$ Addip Faricha \\ 1addipfaricha0368@gmail.com
}

\section{SMA Negeri 1 Abung Semuli Lampung Utara}

\begin{abstract}
The purpose of this study is to increase creativity and PAI learning outcomes for the development of science during the Abasiyah period for students of class XI MIPA 2 SMA Negeri 1 Abungsemuli in semester 2 of the 2019/2020 Academic Year. The implementation of this research is from January 2020 to June 2020. The location of this research is SMA Negeri 1 Abungsemuli. The research subjects were students of class XI MIPA 2 SMA Negeri 1 Abungsemuli, totaling 25 students. The data collection technique was carried out through 2 cycles. The results of the actions carried out in the initial conditions the average value was 55.68 while after the actions were carried out in the first cycle it increased to 66.24. this experienced a very significant increase, namely 5.88\%, while in the second cycle it reached an average value of 75.12 compared to the first cycle, which also increased by $5.88 \%$.
\end{abstract}

Key Word:Learning creativity, learning outcomes, TeTeS TeLOr teaching aids.

\begin{abstract}
Abstrak: Tujuan penelitian ini meningkatkan kreativitas dan hasil belajar PAI materi perkembangan ilmu pengetahuan pada masa Abasiyah bagi siswa kelas XI MIPA 2 SMA Negeri 1 Abungsemuli pada semester 2 Tahun Ajaran 2019/2020. Pelaksanaan penelitian ini pada Januari 2020 sampai Juni 2020. Tempat penelitian ini di SMA Negeri 1 Abungsemuli. Subjek penelitan adalah siswa kelas XI MIPA 2 SMA Negeri 1 Abungsemuli yang berjumlah 25 orang siswa. Teknik pengumpulan data dilaksanakan melalui 2 kali siklus. Hasil tindakan yang dilaksanakan pada kondisi awal nilai rata-rata 55,68 sedang setelah dilaksanakan tindakan pada siklus pertama meningkat menjadi 66,24. ini mengalami peningkatan yang sangat berarti, yakni $5,88 \%$, sedangkan pada siklus kedua mencapai nilai rata-rata 75,12 dibandingkan dengan siklus pertama mengalami kenaikan sebesar 5,88\% pula.
\end{abstract}

Kata Kunci: Kreativitas belajar, hasil belajar, Alat Peraga TeTeS TeLOr.

\section{PENDAHULUAN}

Perkembangan ilmu pengetahuan pada masa Abasiyah adalah materi yang diajarkan pada Pembelajaran PAI di kelas XI Semester 2. Kenyataannya siswa belum optimal dalam kreativitas terbukti memperoleh data rata-rata 0,21 (kurang baik) dan hasil belajar materi tersebut peneliti memperoleh data dari 25 orang siswa dengan nilai terkecil 35, tertinggi 76 , dan 
Peningkatkan Kreativitas Dan Hasil Belajar PAI Materi Perkembangan Ilmu Pengetahuan Pada Masa Abasiyah Melalui Pemanfaatan Alat Peraga Tetes Telor Bagi Siswa Kelas Xi MIPA 2 Sma Negeri 1 Abung Semuli Pada Semester 2 Tahun Ajaran 2019/2020 (Addip Faricha)

rata-ratanya yang didapat begitu rendah perkembangan ilmu pengetahuan pada masa yaitu 55.68 .

Pada Penelitian Tindakan Kelas (PTK) ini peneliti mencoba memanfaatkan alat peraga Teka Teki Santai Tepat Langsung dapat Skor (selanjutnya disebut TeTeS TeLOr) karena alat peraga tersebut sangat menarik buat siswa, diharapkan kreativitas dan hasil belajar bisa mengalami kenaikan paling tidak (minimal) mencapai nilai rata-rata batas tuntas yakni 75. Serta dalam kehidupan sehari-hari siswa membiasakan mempelajari dan mengamalkan semua ilmu pengetahuan, demi meningkatnya iman dan taqwanya terhadap Allah swt. Sehingga menjadi manusia yang beriman juga berilmu. Sebab Allah swt. akan mengangkat orang yang beriman dan berilmu pengetahuan dengan beberapa derajat. Hal ini terdapat dalam Firman Allah swt. Al Qur'an Surat AL Mujadalah 11 dalam kitab Al Qur'an tafsir (Fachrudin \& Irhamah, 2010) sebagai berikut:

$$
\text { يرفع الله الذين امنوا منكم و الذ ين اوتو العلم د }
$$

رجت

Artinya : "Allah swt. akan mening-gikan orang-orang yang beriman diantara kamu dan orang-orang yang diberi ilmu pengetahuan beberapa derajat" (QS. Mujadalah 11).

Penulis yakin bahwa dengan memanfaatkan alat peraga TeTeS TeLOr kreativitas dan hasil belajar PAI materi

Abasiyah dapat mening-kat yaitu siswa dapat mencapai nilai rata-rata 75 dan dapat mencapai batas tuntas minimal $75 \%$ dari jumlah siswa kelas XI MIPA 2 sebagaimana yang sekolah tetapkan dalam KKM. Rumusan masalah pada penelitian ini adalah “Apakah melalui pemanfaatan alat peraga TeTeS TeLOr dapat meningkatkan kreativitas dan hasil belajar PAI materi perkembangan ilmu pengetahuan pada masa Abasiyah bagi siswa kelas XI MIPA 2 SMA Negeri 1 Abungsemuli pada semester 2 tahun ajaran 2019/2020?"

Tujuan penelitian ini adalah melalui pemanfaatan alat peraga TeTeS TeLOr dapat meningkatkan kreativitas dan hasil belajar PAI materi perkembangan ilmu pengetahuan pada masa Abasiyah bagi siswa kelas XI MIPA 2 SMA Negeri 1 Abungsemuli pada semester 2 Tahun Ajaran 2019/2020.

Manfaat pada penelitian ini adalah sebagai berikut.

1. Bagi siswa yaitu untuk meningkatkan kreativitas dan hasil belajar PAI materi perkemba-ngan ilmu pengetahuan pada masa Abasiyah. Serta siswa dapat membiasakan untuk mempelajari berbagai macam ilmu pengetahuan, sehingga kreativitas juga hasil belajarnya bisa meningkat.

2. Bagi guru diharapkan untuk mampu memper-baiki juga meningkatkan sistim 
belajar mengajar PAI khususnya materi perkembangan ilmu pengetahuan pada masa Abasi-yah yang dilaksanakan, guna mengatasi permasalahan yang dihadapi baik guru, siswa maupun sekolah, sehingga apa yang diharapkan (tujuan pendi-dikan Agama Islam) akan dapat tercapai.

3. Bagi sekolah sungguh sangat penting sebab sekolah tidak dapat dipisahkan dengan murid, guru dan sekolah itu sendiri yaitu untuk perbaikan proses pembelajaran dan peningkatan mutu (kualitas) sekolah.

4. Bagi perpustakaan untuk men-capai keberhasilah belajar mengajar di sekolah, dengan tersedianya buku-buku yang dapat menunjang materi semua bidang study. guna menambah wawasan dan pengetahuan dalam bidang keimanan dan ketaqwaan terhadap Allah swt.

Menurut Wardani

"pembelajaran yang kreatif adalah yang dapat mewakili pemikiran dan gagasan serta kreativitas siswa". Apabila dilihat dari aktivitas yang dilakukan siswa, pembelajaran kreatif adalah pembelajaran yang dapat memberikan siswa kesempatan agar dapat merancang, berkreasi, gagasan, pendapat atau pemikiran dengan suatu karya, secara tertulis maupun tidak tertulis. Aktivitas seperti itu akan dapat memberikan rasa puas,mampu berpikir kritis dan imajinasi siswa. Selanjutnya pembelajaran kreatif adalah pembelajaran yang mampu membuat siswanya aktif bertanya (kritis), mengemukakan gagasan, mempertanyakan gagasan orang lain dan mengguna-kan media pembelajaran. Selanjutnya menurut Taylor (dalam Mulyasa, 2010) "untuk dapat mengembangkan kreativitas yang dimiliki siswa bisa dilakukan dengan cara menyediakan sumber belajar untuk bisa menemukan gagasan, dan memberanikan siswa agar bisa memenipulasi benda-benda dan ide".

Morison berpendapat dalam bukunya Syamsuddin (2009) bahwa "hasil belajar yang merupakan suatu perubahan sungguhsungguh pada pribadi dan prilaku setiap orang bisa bersifat permanen". Apalagi jika telah menjadi suatu kebiasaan, walaupun kita bisa saja kurang memiliki kesadaran lagi utamanya untuk hasil belajar yang kaitannya dengan proses dan hasil dari perkembangan (berjalan, menulis, bicara dan sebagainya). Selanjutnya Syamsuddin (2009) menyatakan: "kejadian lainnya yang sering sekali dialami juga ialah kita seperti merasakan bahwa hasil belajar itu seperti tidak mengalami kenaikan (mapan) untuk jenjang waktu tertentu". Kemudian hal seperti itu dikatakan sebagai suatu kebosanan untuk belajar, daya ingatan yang kita miliki tidak lagi mampu untuk mengadakan informasi. Jika dibuat dalam bentuk kurva kenaikan hasil belajar, maka tampak seperti garis yang mendatar atau 
Peningkatkan Kreativitas Dan Hasil Belajar PAI Materi Perkembangan Ilmu Pengetahuan Pada Masa Abasiyah Melalui Pemanfaatan Alat Peraga Tetes Telor Bagi Siswa Kelas Xi MIPA 2 Sma Negeri 1 Abung Semuli Pada Semester 2 Tahun Ajaran 2019/2020 (Addip Faricha)

disebut dengan learning plateu. Kebosanan

ketika belajar ini biasanya terjadi sumbernya ada pada faktor fisik yang letih, physiological limits (batas-batas kemampuan fisik kita), kejemuan (boring). Gagne (dalam Suprayekti, 2009) "mengklarifikasikan hasil belajar dikategorikan menjadi lima yaitu informasi ferbal, kemahiran intelektual, strategi kognitif yang termasuk ranah kognitif, sikap dari ranah afektif dan keterampilan motorik dari ranah psikomotorik. Hasil pada ranah kognitif dari Gagne ini telah dipilah menjadi tiga yaitu: (1) Informasi verbal adalah suatu kemampuan untuk menyimpan informasi dalam ingatan. (2) Keterampilan intelektual yaitu berupa kemampuan dalam menggunakan simbol untuk berinteraksi, mengorganisir dan mem-bentuk arti. (3) Strategi kognitif merupakan kemampuan untuk mengatur dan mengontrol proses berpikir dalam diri sendiri. Hasil belajar motorik berhubungan dengan melakukan gerakan tubuh dengan lancar dan tepat. Sedangkan hasil belajar sikap adalah kondisi mental yang memengaruhi pemilihan prilakunya."

\section{Pendidikan Agama Islam}

Pendidikan Agama Islam (PAI) menurut Depdiknas (2006) suatu pelajaran bukan hanya menggiring siswa agar mampu untuk bisa menguasai berbagai macam kajian keislaman, namun PAI lebih mengutamakan agar siswa dapat menguasai kajian keislaman tersebut dan juga dapat mengimplementasikannya di dalam keseharian pada masyarakat luas. Artinya PAI bukan hanya mengutamakan aspek kognitif saja, melainkan ada yang lebih penting untuk diutamakan yaitu aspek afektif dan psikomotoriknya.

\section{Alat Peraga TeTeS TeLOr}

Menurut Andreas (dalam Masrukhan, 2004) bahwa "media dapat diartikan sebagai sesuatu yang dapat dimanfaatkan dalam proses komunikasi kepada siswa agar siswa dapat belajar". Dalam aktivitas pembelajaran, media dapat diartikan sebagai sesuatu yang dapat membawa informasi dan pengetahuan dalam interaksi antara guru dan siswa (Sutikno \& Sobri, 2009). Sedangkan alat peraga merupakan media pembelajaran yang mengandung ciri-ciri konsep yang dipelajari. "Fungsi utama alat peraga adalah untuk dapat menurunkan suatu keabstrakan dari konsep agar siswa mampu menangkap arti dari konsep tersebut" (Budiyono, 2012). Alat peraga TeTeS TeLOr merupakan media pembelajaran yang dapat berguna untuk belajar secara konkret mengenai pengetahuan berupa materi perkembangan ilmu pengetahuan pada masa Abasiyah, sehingga siswa mengetahui dan mengalami secara langsung penggunaan alat peraga 
TeTeS TeLOr tersebut. Tujuannya siswa mampu menjawab pertanyaan yang ada di dalam teka teki tersebut secara langsung dan akan mendapat skor/nilai, sehingga para siswa langsung dapat mengetahui hasil belajarnya.

Selanjutnya pada kerangka berpikir yang direncanakan dibagi menjadi dua siklus. Siklus ke-1 yaitu: kelompok besar yang setiap kelompok terdiri atas 6-7 siswa, selanjutnya disiklus ke-2 yaitu: kelompok kecil yang setiap kelompok terdiri atas 3-4 siswa, selanjutnya peneliti memberikan tes tertulis kembali agar dapat melakukan perbandingankreativitas dan hasil belajar siklus ke-1 dengan siklus ke-2. Setelah dilakukannya hal tersebut diseimpulkan dugaan bahwa dengan pemanfaatan alat peraga TeTeS TeLOr dapat meningkatkan hasil belajar Pendidikan Agama Islam khususnya materi perkembangan ilmu penge-tahuan pada masa Abasiyah bagi siswa kelas XI MIPA 2 SMA Negeri 1 Abungsemuli pada semester 2 Tahun Ajaran 2019/2020.

\section{METODE}

Penelitian ini merupakan penelitian tindakan kelas. Tempat Penelitian ini pada SMA Negeri 1 Abungsemuli, yang terletak di Kecamatan Abung Semuli, Kabupaten Lampung Utara. Sekolah tersebut tempat penulis mengajar, sehingga setiap hari penulis dapat bertemu dan mengadakan pengamatan terhadap para siswa. Penelitian dilaksanakan pada semester genap Tahun Ajaran 2019/2020 yakni dimulai pada Januari 2020 - Juni 2020. Subjek penelitian dan objek Penelitian yaitusiswa SMA Negeri 1 Abungsemuli kelas XI MIPA 2 Tahun Ajaran 2019/2020 pada semester 2 yang jumlahnya 25 siswa. Masalah yang dialami siswa pada kelas tersebut adalah rendahnya kreativitas dan hasil belajar PAI materi sejarah perkembangan ilmu pengetahuan pada masa Abasiyah. Data dan sumber data yaitu mengenai kreativitas dan hasil belajar saat kondisi awal, siklus pertama dan juga siklus kedua, serta perbandingannya. Alat pengumpulan data terdiri: lembar pengamatan, butir soal tes kognitif, Kamera, Buku induk siswa, dan Alat peraga TeTeS TeLOr. Analisis datanya menggunakan lembar pengamatan yang dianalisa agar dapatdiketahui sudah sejauh manakah kreativitas siswa dalam mengikuti proses pembelajaran baik secara kelompok maupun pribadi, butir soal tes kognitif kemudian dilakukan analisis menggunakan Diskriptif Komperatif. Indikator keberhasilan dapat di ketahui melalui Hasil pengamatan kreativitas belajar meliputi keceriaan, berani mengemukakan pendapat, kritis, dan berani dalam menjawab pertanyaan dari peneliti, dalam pengamatan peneliti mencatat berapa siswa yang 
Peningkatkan Kreativitas Dan Hasil Belajar PAI Materi Perkembangan Ilmu Pengetahuan Pada Masa Abasiyah Melalui Pemanfaatan Alat Peraga Tetes Telor Bagi Siswa Kelas Xi MIPA 2 Sma Negeri 1 Abung Semuli Pada Semester 2 Tahun Ajaran 2019/2020 (Addip Faricha)

kelihatan sudah ceria, sudah berani untuk dipelajari dan dibahas bermengemukakan pendapat, bertanya dan menjawab pertanyaan dari pene-liti, selanjutnya dihitung berapa yang sudah kreativitas dibagi jumlah siswa, maka dapat data tentang kreativitas siswa, selanjut-nya peneliti buat kategori 0,80 - 1,00 (sangat baik), 0,60 - 0,79 (baik), 0,40 - 0,59 (cukup baik), 0,20 - 0,39 (kurang baik) dan 0,1 0,19 (sangat kurang baik). Adapun Tes kognitif untuk mendapatkan data hasil belajar siswa jikamendapat nilai 75 keatas dapat dikategorikan tuntas, sedangkan kurang dari 75 dikate-gorikan belum tuntas, Penerapan konsep dapat dikuasai siswa dilihat dari nilai yang diperoleh.

Prosedur penelitian Tiap Siklus baik siklus pertama maupun siklus kedua melalui beberapa langkah-langkah sbb: Persiapan (Planning) meliputi: Pembuatan jadwal pene-litian, Perangkat pembelajaran (Silabus, RPP, LKS, TTS, dsb.), Lembar tes, Buku induk siswa, Lembar penugasan untuk berdis-kusi beserta kelompoknya dan mempresentasikan hasilnya. Tindakan (Acting) bahwa siswa telah diberi penjelasan kalau akan dilakukan Penelitian Tindakan Kelas (PTK) dimaksud agar siswa lebih serius untuk melaksanakan kegiatan pembelajaran.Selanjut-nya alat peraga TeTeS TeLOr tersebut untuk diisi dengan jawaban yang sesuai, kemudian jawaban tersebut di masukkan kedalam kolom-kolom alat peraga tersebut yang telah disediakan sama.Observasi meliputi: Proses belajar siswa baik secara kelompok maupun secara individu, Kreativi-tas siswa terhadap tugas yang diberikan guru, Antusias siswa dalam menjawab pertanyaan, Kemampuan siswa dalam mempre-sentasikan hasil diskusi. Kemudian melakukan refleksi dengan melihat hasil melalui pengumpulan data dari:Lembar pengamatan, Tes Kognitif, Buku induk siswa, Kebenaran dalam menjawab pertanyaan, Dari hasil tersebut apabila telah didapatkan siswa telah mencapai indikator kinerja yang diharapkan, maka penelitian dihentikan. Namun apa-bila dibawah indikator kinerja yang diharapkan, akan dilanjut-kan rencana tindakan untuk pelak-sanaan siklus selanjutnya.

\section{HASIL DAN PEMBAHASAN}

\section{Diskripsi Data Kondisi Awal}

Data yang diperoleh terkait kreativitas siswa adalah yang ceria 9 siswa dan 16 siswanya kurang ceria, siswa berani mengemukakan pendapat 4 siswa dan 21 siswa belum berani mengemukakan pendapatnya, selanjutnya yang berani untuk bertanya 7 siswa artinya yang belum memiliki keberanian untuk bertanya ada 18 siswa, yang mau menjawab pertanyaan dari 
peneliti terdapat 6 siswa dan yang belum berani menjawab perta-nyaan dari peneliti 19 siswa. Selanjutnya disajikan kreativitas siswa pada kondisi awal dalam tabel sebagai berikut:

Aspek Kreativitas Siswa Kondisi Awal

\begin{tabular}{|c|l|c|c|}
\hline \multirow{2}{*}{ No } & \multirow{2}{*}{ Aspek Kreativitas Siswa } & \multicolumn{2}{|c|}{ Jumlah Siswa } \\
\cline { 3 - 4 } & & Sudah & Belum/Kurang \\
\hline 1 & Ceria & 9 & 16 \\
\hline 2 & Berani mengemukakan pendapat & 4 & 21 \\
\hline 3 & Berani bertanya & 7 & 18 \\
\hline 4 & Berani menjawab & 6 & 19 \\
\hline
\end{tabular}

Selanjutnya akan peneliti sajikan skor kreativitas siswa dari data tersebut di atas sebagai berikut :

Skor Kreativitas Siswa Kondisi Awal

\begin{tabular}{|c|l|c|}
\hline NO & \multicolumn{1}{|c|}{ KREATIVITAS SISWA } & RERATA \\
\hline 1 & Ceria & 0.36 \\
\hline 2 & Berani mengemukakan pendapat & 0.16 \\
\hline 3 & Berani bertanya & 0.28 \\
\hline 4 & Berani menjawab & 0.24 \\
\hline & Rerata & 0.21 \\
\hline & Kategori & Kurang baik \\
\hline
\end{tabular}

Sedangkan hasil belajar yang didapat yaitu nilai terendahnya 35 , dan nilai tertingginya 76 , sedangkan nilai rata - rata kelasnya 55.68. Data ini dikategorikan sangat rendah, tersaji pada tabel sebagai berikut: 
Data Nilai Kondisi Awal

Semester 2 Tahun Ajaran 2019/2020 (Addip Faricha)

\begin{tabular}{|c|l|c|}
\hline NO & \multicolumn{1}{|c|}{ URAIAN } & NILAI \\
\hline 1. & Nilai terendah & 35 \\
\hline 2. & Nilai tertinggi & 76 \\
\hline 3. & Nilai rata - rata kelas & 55.68 \\
\hline 4. & Rentang Nilai & 41 \\
\hline
\end{tabular}

\section{Diskripsi Data Siklus Pertama}

Data kreativitas siswa

1. Aspek Ceria

Terdapat 25 siswa di pertemuan ke-1, 8 siswa terlihat ceria dan yang kurang ceria 17 siswa. Di pertemuan ke-2 terdapat 13 siswa yang ceria artinya 12 siswa kurang ceria.

2. Aspek berani mengemukakan pendapat Dari 25 siswa yang berani untuk mengemukakan pendapat pada pertemuan ke-1 ada 12siswa, artinya siswa yang kurang berani mengemukakan penda-pat yaitu ada 13 siswa, sementara itu pertemuan ke-2 yang berani mengemukakan pendapat ada 15 siswaartinya yang kurang berani mengemukakan penda-pat ada 10 siswa.

3. Aspek berani bertanya
Terdapat 25 siswa di pertemuan ke-1 siklus pertama yang berani untuk bertanya ada 5 dan yang belum berani bertanya ada 20 siswa. Di pertemuan ke2 yang telah berani untuk bertanya ada 8 siswa dan yang belum memiliki keberanian untuk berta-nya ada 17 siswa.

4. Aspek Berani Menjawab

Dari 25 siswa yang berani dalam menjawab per-tanyaan pada perte-muan ke-1 ada 7 siswa, artinya yang belum memiliki keberanian untuk menjawab yaitu ada 18 siswa, sementara itu pertemuan ke-2 siswa yang telah mau untuk menjawab ada 10 siswa dan 15 siswa masih belum memiliki keberanian dalam menjawab pertanyaan yang diberikan.Peneliti sajikan Rerata skor pengamatan kreativitas pada siklus pertama sebagai berikut : 
Skor Kreativitas Siswa pada Siklus Pertama

\begin{tabular}{|c|l|c|c|c|}
\hline \multirow{2}{*}{ No } & \multirow{2}{*}{ Aspek Pengamatan } & \multicolumn{2}{|c|}{ Pertemuan } & \multirow{2}{*}{ Rerata } \\
\cline { 3 - 4 } & & $\mathbf{1}$ & $\mathbf{2}$ & \\
\hline 1 & Ceria & 0.32 & 0,52 & 0,42 \\
\hline 2 & Berani mengemukakan pendapat & 0,48 & 0,60 & 0.54 \\
\hline 3 & Berani bertanya & 0,20 & 0,32 & 0,26 \\
\hline 4 & Berani menjawab & 0,28 & 0,40 & 0,34 \\
\hline & Rerata & 0,32 & 0,47 & 0,39 \\
\hline & Kategori & & & Kurang Baik \\
\hline
\end{tabular}

Data Hasil Belajar

Pada siklus pertama data hasil belajar yang terendah 42 , tertinggi 84 dan rata-rata kelas 66.24. Jika dilihat dari nilai rata - rata kelas yang awalnya hanya 55.68, maka ditargetkan saat selesai penelitian nilai rataratanya bisa mencapai 75 . Walaupun nilai

Data Nilai Hasil Belajar Siklus Pertama

\begin{tabular}{|c|l|c|}
\hline NO & \multicolumn{1}{|c|}{ URAIAN } & NILAI \\
\hline 1. & Nilai terendah & 42 \\
\hline 2. & Nilai tertinggi & 84 \\
\hline 3. & Nilai rata - rata kelas & 66.24 \\
\hline 4. & Rentang Nilai & 42 \\
\hline
\end{tabular}

Selanjutnya disajikan tabel mengenai frekuensi nilai hasil belajar pada siklus pertama sebagai berikut :

Data Frequensi Nilai hasil Belajar Siklus Pertama

\begin{tabular}{|c|c|c|}
\hline NO & INTERVAL NILAI & FREQUENSI NILAI \\
\hline 1 & $80-89$ & 1 \\
\hline 2 & $70-79$ & 8 \\
\hline 3 & $60-69$ & 12 \\
\hline 4 & $50-59$ & 3 \\
\hline 5 & $40-49$ & 1 \\
\hline
\end{tabular}

rata-ratanya telah mengalami kenaikan yakni dari 55.68 menjadi 66.24, ini artinya nilai tersebut telah mengalami kenaikan sebesar 10.56 poin atau 5.88\%. Akan peneliti sajikan berupa tabel sebagai berikut: 
Kemudian disajikan perbandingan nilai hasil belajar yang terendah, tertinggi, reratanya, dan rentang nilai hasil belajar pada kondisi awal dengan nilai hasil belajar pada siklus pertama. Peneliti sajikan dalam tabel sebagai berikut:

Perbandingan Nilai Hasil Belajar

Kondisi Awal Dengan Siklus Pertama

\begin{tabular}{|c|l|c|c|c|c|}
\hline N & URAIAN & $\begin{array}{c}\text { KONDI } \\
\text { AWAL }\end{array}$ & $\begin{array}{c}\text { SIKLUS } \\
\text { PERTAM } \\
\text { A }\end{array}$ & $\begin{array}{c}\text { TERPAUT } \\
\text { POIN / \% }\end{array}$ & KET. \\
\hline 1. & $\begin{array}{l}\text { Nilai } \\
\text { Terendah }\end{array}$ & 35 & 42 & $7 / 2.45 \%$ & Meningkat \\
\hline 2. & Nilai Tetinggi & 76 & 84 & $8 / 6.08 \%$ & Meningkat \\
\hline 3. & Rerata & 55.68 & 66.24 & $10.56 / 5.88 \%$ & Meningkat \\
\hline 4. & Rentang Nilai & 41 & 42 & & \\
\hline
\end{tabular}

\section{Diskripsi Data Siklus Kedua}

\section{Data kreativitas Siswa}

\section{Aspek Ceria}

Dari 25 siswa di pertemuan ke-1 yang terlihat ceria ada 16 siswa dan kurang ceria ada 16 siswa. Sedangkan dipertemuan ke-2 ada 20 siswa yang ceria dan 5 siswa kurang terlihat ceria.

2. Aspek berani mengemukakan pendapat Dari 25 siswa yang berani mengemukakan pendapat di pertemuan ke-1 terdapat 15 siswa dan yang kurang berani mengemukakan pendapat 10 siswa. Pada pertemuan ke-2 ada 19 siswa yang berani mengemukakan pendapat dan yang kurang berani mengemukakan penda-pat 6 orang siswa.

3. Aspek berani bertanya

Dari 25 siswa dipertemuan ke-1 siklus kedua terdapat 13 siswa berani untuk bertanya dan yang belum berani bertanya terdapat 12 siswa. Sementara itu dipertemuan ke-2 terdapat 16 siswa yang memiliki keberanian untuk bertanya dan 9 siswa belum memiliki keberanian untuk bertanya.

4. Aspek Berani Menjawab

Dari 25 siswa yang memiliki keberanian untuk menjawab per-tanyaan pada pertemuan ke-1 terdapat 14 siswa dan yang belum memiliki keberanian untuk menjawab ada 11 siswa. Sementara itu 
pertemuan ke-2 yang memiliki keberanian menjawab ada 18 siswa dan 7 siswa belum memiliki keberanian untuk menjawab pertanyaan dari peneliti. Beri-kut disajikan rerata skor pengamatan kreativitas dalam tabel sebagai berikut :

Skor Kreativitas Siswa pada Siklus Kedua

\begin{tabular}{|c|l|c|c|c|}
\hline \multirow{2}{*}{ No } & \multirow{2}{*}{ Aspek Pengamatan } & \multicolumn{2}{|c|}{ Pertemuan } & \multirow{2}{*}{ Rerata } \\
\cline { 3 - 4 } & & $\mathbf{1}$ & $\mathbf{2}$ & \\
\hline 1 & Ceria & 0.64 & 0,80 & 0,72 \\
\hline 2 & Berani mengemukakan pendapat & 0,60 & 0,76 & 0.68 \\
\hline 3 & Berani bertanya & 0,52 & 0,64 & 0,58 \\
\hline 4 & Berani menjawab & 0,56 & 0,72 & 0,64 \\
\hline & Rerata & 0,58 & 0,73 & 0,66 \\
\hline & Kategori & & & Baik \\
\hline
\end{tabular}

Data Hasil Belajar

Nilai hasil belajar terendah pada siklus ke-2 adalah 47, nilai tertinggi 95, dan nilai rata - rata kelas 75.12. Ditargetkan setelah selesainya penelitian ini dapat mencapai nilai rata-ratanya 75 . Walaupun kenaikan nilai rata-ratanya dari 66.24 menjadi 75.12 artinya mengalami kenaikan 8.88 poin atau $5.88 \%$. Disajikan berupa tabel sebagai berikut:

Data Nilai Hasil Belajar Siklus Kedua

\begin{tabular}{|c|l|c|}
\hline NO & \multicolumn{1}{|c|}{ URAIAN } & NILAI \\
\hline 1. & Nilai terendah & 47 \\
\hline 2. & Nilai tertinggi & 95 \\
\hline 3. & Nilai rata - rata kelas & 75.12 \\
\hline 4. & Rentang Nilai & 48 \\
\hline
\end{tabular}

Selanjutnya disajikan tabel tentang frequensi nilai hasil belajar pada siklus kedua sebagai berikut : 
Peningkatkan Kreativitas Dan Hasil Belajar PAI Materi Perkembangan Ilmu Pengetahuan Pada Masa Abasiyah Melalui Pemanfaatan Alat Peraga Tetes Telor Bagi Siswa Kelas Xi MIPA 2 Sma Negeri 1 Abung Semuli Pada Semester 2 Tahun Ajaran 2019/2020 (Addip Faricha)

Data Frequensi Nilai hasil Belajar Siklus Kedua

\begin{tabular}{|c|c|c|}
\hline \multirow{2}{*}{ NO } & \multicolumn{2}{|c|}{ NILAI } \\
\cline { 2 - 3 } & INTERVAL & FREQUENSI \\
\hline 1 & $90-100$ & 5 \\
\hline 2 & $80-89$ & 1 \\
\hline 3 & $70-79$ & 13 \\
\hline 4 & $60-69$ & 3 \\
\hline 5 & $50-59$ & 2 \\
\hline 6 & $40-49$ & 1 \\
\hline
\end{tabular}

Selanjutnya disajikan perbandingan hasil belajar terendah, tertinggi, reratanya, dan rentang hasil belajar pada siklus pertama dengan hasil belajar pada siklus kedua. Disajikan dalam tabel berikut:

Perbandingan Nilai Hasil Belajar

Siklus Pertama dengan Siklus Kedua

\begin{tabular}{|c|l|c|c|c|c|}
\hline NO & URAIAN & $\begin{array}{c}\text { SIKLUS } \\
\text { PERTAMA }\end{array}$ & $\begin{array}{c}\text { SIKLUS } \\
\text { KEDUA }\end{array}$ & $\begin{array}{c}\text { TERPAUT } \\
\text { POIN / \% }\end{array}$ & KET. \\
\hline 1. & $\begin{array}{l}\text { Nilai } \\
\text { Terendah }\end{array}$ & 42 & 47 & $5 / 2.10 \%$ & Meningkat \\
\hline 2. & $\begin{array}{l}\text { Nilai } \\
\text { Tetinggi }\end{array}$ & 84 & 95 & $11 / 9.24 \%$ & Meningkat \\
\hline 3. & Rerata & 66.24 & 75.12 & $8.88 / 5.88 \%$ & Meningkat \\
\hline 4. & $\begin{array}{l}\text { Rentang } \\
\text { Nilai }\end{array}$ & 42 & 48 & & \\
\hline
\end{tabular}

\section{Pembahasan}

\section{Pembahasan Tindakan}

Berdasarkan observasi yang di-lakukan pada tindakan dikondisi awal maka dapat diuraikan bahwa peneliti belumlah memanfaatkan alat peraga TeTeS
TeLOr, namun baru memanfaatkan metode ceramah secara klasikal, namun pada siklus per-tama peneliti sudah meman-faatkan alat peraga $\mathrm{TeTeS}$ TeLOr dengan kelompok besar, begitu juga pada siklus kedua juga sudah memanfaatkan alat peraga TeTeS TeLOr 
dengan kelompok kecil.akan peneliti sajikan data tabel sebagai berikut :

Tindakan Kondisi Awal, Siklus Pertama dan Siklus Kedua

\begin{tabular}{|c|c|c|c|}
\hline & Kondisi awal & Siklus pertama & Siklus kedua \\
\hline \multirow{7}{*}{ Tindakan } & Belum & Sudah & Sudah \\
& memanfaatkan & memanfaatkan & memanfaatkan \\
& alat peraga masih & alat peraga & alat peraga \\
& menggunakan & TeTeS TeLOr & TeTeS TeLOr \\
& metode ceramah & dengan & dengan kelompok \\
& secara klasikal & kelompok besar & kecil \\
\hline
\end{tabular}

\section{Hasil Pengamatan/Observasi}

Kreativitas siswa mulai terlihatyang dibuktikan denganpara siswa sudah mulai ceria, berani mengemukakan pendapat, berani bertanya dan menjawab, tapi berdasarkan pengamatan kreativi-tas siswa masih dikategorikan kurang baik, karena itu diperlukannya perbaikan pada siklus berikutnya, pada siklus kedua ini kreativitas siswa sudah baik dikarenakan para siswa sudah ceria, berani mengemukakan pendapat, berani bertanya kepada peneliti dari hal-hal yang belum terlalu dimengerti, serta mulai berani menjawab per-tanyaan yang diberikan, dan pada siklus kedua ini krativitas siswa sudah dikategorikan baik. akan peneliti sajikan tabel sebagai

Proses Kondisi Awal, Siklus Pertama dan Siklus Kedua

berikut.

\begin{tabular}{|c|c|c|c|}
\hline \multirow{2}{*}{ KONDISI AWAL } & \multicolumn{2}{|c|}{ SIKLUS } \\
\cline { 3 - 4 } & & PERTAMA & KEDUA \\
\hline \multirow{4}{*}{} & Masih terdapat siswa & Sudah ceria, sudah & Sudah ceria, sudah \\
& yang kurang ceria, & berani & berani \\
& belum berani & mengemukakan & mengemukakan \\
mengemukakan & pendapat, sudah & pendapat, sudah \\
berani bertanya dan & berani bertanya dan \\
pendapat, belum & sudah berani & sudah berani \\
& berani bertanya dan & menjawab, namun & menjawab, dan \\
& belum berani & dikategorikan masih & dikategorikan sudah \\
& menjawab & kurang baik & baik \\
\hline
\end{tabular}


Peningkatkan Kreativitas Dan Hasil Belajar PAI Materi Perkembangan Ilmu Pengetahuan Pada Masa Abasiyah Melalui Pemanfaatan Alat Peraga Tetes Telor Bagi Siswa Kelas Xi MIPA 2 Sma Negeri 1 Abung Semuli Pada Semester 2 Tahun Ajaran 2019/2020 (Addip Faricha)

Disajikan secara rinci kategori skor kreativitas siswa dalam tabel berikut :

Kategori Skor Kreativitas Siswa Tiap Siklus

\begin{tabular}{|c|l|c|c|c|}
\hline \multirow{2}{*}{ NO } & \multirow{2}{*}{ ASPEK PENGAMATAN } & \multirow{2}{*}{ KONDISI AWAL } & \multicolumn{2}{|c|}{ SIKLUS } \\
\cline { 4 - 5 } & & & Pertama & Kedua \\
\hline 1 & Ceria & 0.36 & 0.42 & 0.72 \\
\hline 2 & $\begin{array}{l}\text { Beranimengemukakan } \\
\text { pendapat }\end{array}$ & 0.16 & 0.54 & 0.68 \\
\hline 3 & Beranian bertanya & 0.28 & 0.26 & 0.58 \\
\hline 4 & Beranianmenjawab & 0.24 & 0.34 & 0.64 \\
\hline & Rerata & 0.21 & 0.39 & 0.66 \\
\hline & Kategor & Kurang Baik & Kurang Baik & Baik \\
\hline
\end{tabular}

3. Data Hasil belajar

Data hasil belajar yang peneliti peroleh melalui hasil tes para siswa dikondisi awal rata-ratanya55,68, pada siklus ke-1 rata-ratanya 66,24, dan hasil tes pada siklus ke-2 telah mencapai nilai rataratanya75,12, ini merupakan peningkatan yang cukup berarti. Untuk lebih jelasnyadisajikan dalam tabel di bawah sebagai berikut:

Nilai Rata-Rata Kondisi Awal, Siklus Pertama, dan Siklus Kedua

\begin{tabular}{|l|c|c|c|}
\hline & $\begin{array}{c}\text { Kondisi } \\
\text { Awal }\end{array}$ & $\begin{array}{c}\text { Siklus } \\
\text { Pertama }\end{array}$ & $\begin{array}{c}\text { Siklus } \\
\text { Kedua }\end{array}$ \\
\hline $\begin{array}{l}\text { Nilai rata - rata hasil } \\
\text { belajar PAI materi } \\
\text { perkembangan ilmu } \\
\text { pengetahuan pada masa } \\
\text { Abasiyah }\end{array}$ & 55.68 & 66.24 & 75.12 \\
\hline
\end{tabular}

Selanjutnya disampaikan juga mengenai hasil belajar dan peningkatannya baik untuk kondisi awal, siklus pertama dan siklus kedua. Kondisi awal nilai rataratanya adalah 55,68, sementara itu di siklus pertama nilai rata-ratanya adalah
66,24, dan mencapai 75,12 pada siklus kedua. Bila peneliti bandingkan dilihat dari peningkatannya maka dikondisi awal dengan siklus pertama mengalami peningkatan sebesar 10,56 poin atau setara dengan 5,88\%, kemudian disiklus pertama 
dengan siklus kedua mengalami sebesar 5,88\%. Selanjutnya disajikan pada peningkatan sebesar 8,88 poin atau naik tabel berikut:

\section{Perbandingan Nilai dan Peningkatannya}

Pada Kondisi Awal, Siklus Pertama, dan Siklus Kedua

\begin{tabular}{|c|c|c|c|c|}
\hline $\begin{array}{c}\text { KONDISI } \\
\text { AWAL }\end{array}$ & \multicolumn{2}{|c|}{ SIKLUS PERTAMA } & \multicolumn{2}{c|}{ SIKLUS KEDUA } \\
\hline Nilai rata-rata & $\begin{array}{c}\text { Nilai } \\
\text { rata-rata }\end{array}$ & $\begin{array}{c}\text { Kenaikan } \\
\text { poin/\% }\end{array}$ & $\begin{array}{c}\text { Nilai } \\
\text { rata-rata }\end{array}$ & $\begin{array}{c}\text { Kenaikan } \\
\text { poin/\% }\end{array}$ \\
\hline 55.68 & 66.24 & $10.56 / 5.88 \%$ & 75.12 & $8.88 / 5.88 \%$ \\
\hline
\end{tabular}

Dengan demikian dapat disimpulkan sementara melalui hasil pembahasan nilai hasil belajar PAI materi perkembangan ilmu pengetahuan pada masa Abasiyah dengan memanfaatkan alat peraga TeTeS TeLOr dapat meningkatkan kreativitas belajar PAI materi perkembangan ilmu pengetahuan pada masa Abasiyah. Sedangkan proses pembelajaran tersebut membawa dampak meningkatnya hasil bela-jarnya, apabila dilihat melalui rata-rata nilai yang didapat dari kondisi awal, siklus pertama sampai siklus kedua yang selalu terjadi peningkatan yakni antara kondisi awal dengan siklus pertama mengalami peningkatan sebesar 10,56 poin atau $5,88 \%$ dan antara kondisi awal dengan siklus kedua meningkat sebesar 8,88 poin / $5.88 \%$.

\section{Hasil Tindakan}

Dari hasil tindakan diatas maka secara teoritik bahwa model pembelajaran dengan memanfaatkan alat peraga TeTeS TeLOr dapat meningkatkan kreativitas siswa dan hasil belajar PAI materi perkembangan ilmu penge-tahuan pada masa Abasiyah, siswa lebih ceria, berani mengemukakan pendapat, bertanya, dan menjawab setiap pertanyaan yang diberikan. Kemudian menurut teori empirik hasil penelitian yang di laksanakan yaitupada kondisi awal yang mengalami rata rata menca-pai nilai 55,68, sedang setelah dilaksanakan penelitian pada siklus pertama mencapai nilai 66,24. ini mengalami kenaikan yakni mengalami kenaikan sebesar 10,56 poin atau $5,88 \%$. 
Peningkatkan Kreativitas Dan Hasil Belajar PAI Materi Perkembangan Ilmu Pengetahuan Pada Masa Abasiyah Melalui Pemanfaatan Alat Peraga Tetes Telor Bagi Siswa Kelas Xi MIPA 2 Sma Negeri 1 Abung Semuli Pada

\section{SIMPULAN}

Memperhatikan data kreativitas dan hasil belajar yang telah peneliti bandingkan dari kondisi awal, siklus pertama dan siklus kedua yang selalu meningkat, maka dapat disimpulkan melalui pemanfaatan alat peraga TeTeS TeLOr dapat meningkatkan kreativitas dan hasil belajar PAI materi sejarah perkembangan ilmu pengetahuan pada masa Abasiyah bagi siswa kelas XI MIPA 2 SMA Negeri 1 Abungsemuli pada semester 2 Tahun Ajaran 2019/2020.

Beberapa saran atau sumbangan pemikiran: (1) kepada para siswa muslim/muslimah diharapkan agar selalu
Semester 2 Tahun Ajaran 2019/2020 (Addip Faricha) menyadari bahwasanya mempelajari perkembangan ilmu pengetahuan pada masa yang lalu sangat penting untuk meningkatkan kreativitas dan semangat dalam menuntut ilmu; (2) kepada para guru PAI hendaknya memahami hasil penelitian ini sehingga ketika melaksanakan pembelajaran Pendidikan Agama Islam khususnya Al Qur'an materi perkembangan ilmu pengetahuan pada masa Abasiyah dapat menggunakan model pembelajaran dengan memanfaatkan alat peraga TeTeS TeLOr sebagai opsi atau sebagai rujukan, agar pembelajaran lebih berhasil dan meningkat baik aktivitas siswa maupun hasil belajarnya.

\section{DAFTAR PUSTAKA}

Budiyono. (2012). Model, Media, dan Evaluasi Pembelajaran Matematika, Modul Pendidikan dan Pelatihan Profesi Guru (PLPG). Universitas Sebelas Maret.

Depdiknas. (2006). Model Silabus Pendidikan Agama Islam. Direktorat Jendral Manajemen Pendidikan Dasar dan Sekolah Menengah Atas.

Fachrudin, A., \& Irhamah, S. (2010). Al Qur'an Tafsir Al Hidayah. Cempaka Putih.

Masrukhan. (2004). Matematika dan Alat Peraga. majalah Fasilitator Edisi IV.

Mulyasa, E. (2010). Standar Kompetensi dan Sertifikasi Guru. PT. Remaja Rosda Karya.

Suprayekti. (2009). Interaksi Belajar Mengajar. Depdiknas Direktorat Tenaga Kependidikan.

Sutikno, \& Sobri, M. (2009). Belajar dan Pembelajaran. Prospect.

Syamsuddin, A. (2009). Psykologi kependidikan. PT. Remaja Rosdakarya.

Wardani, S. (2020). Strategi Pendekatan Metode Pembelajaran Matematika di Sekolah Dasar. P4TK Matematika. 